\title{
Franciscana strandings on the north coast of Santa Catarina State and insights into birth period
}

\author{
Marta Jussara Cremer * \\ Camila Meirelles Sartori \\ Annelise Colin Holz \\ Beatriz Schulze \\ Natacha Zimmermann dos Santos \\ Ana Kássia de Moraes Alves \\ Renan Lopes Paitach \\ Projeto Toninhas, Universidade da Região de Joinville \\ Caixa Postal 110, CEP 89240-000, São Francisco do Sul - SC, Brasil \\ * Autor para correspondência \\ mjc2209@yahoo.com.br
}

Submetido em 21/11/2012

Aceito para publicação em 08/08/2013

\section{Resumo}

Encalhes de toninhas no litoral norte de Santa Catarina e informações sobre o período de nascimento. A toninha (Pontoporia blainvillei) é o pequeno cetáceo mais ameaçado do Atlântico Sul Ocidental. A captura acidental em redes de pesca é o maior problema para esta espécie ao longo de sua distribuição. As toninhas mortas encontradas nas praias são uma importante fonte de informações. O objetivo deste trabalho foi analisar os registros de carcaças de toninhas encontradas mortas no litoral norte de Santa Catarina, incluindo a Baía da Babitonga. Entre janeiro de 2001 e novembro de 2012 foram registradas 54 carcaças de toninhas. Entre os meses de agosto e outubro foram registradas 28 carcaças (52\%), sendo que o número mais elevado (oito indivíduos) foi encontrado em 2011. Levando em conta que estas informações não são decorrentes de um esforço sistematizado, não podemos considerar que esta seja uma estimativa de mortalidade. O maior animal registrado foi uma fêmea, com $142 \mathrm{~cm}$ de comprimento. Dentre os animais recuperados, 10 (18,5\%) tinham comprimento total inferior a $80 \mathrm{~cm}$, sendo considerados fetos ou filhotes. Estes registros indicam que o principal período de nascimento de toninhas em Santa Catarina é de outubro a janeiro. As informações aqui apresentadas contribuem para o conhecimento desta espécie no Estado.

Palavras-chave: Encalhes; Período de nascimento; Pontoporia blainvillei; Santa Catarina

\section{Abstract}

Franciscana, Pontoporia blainvillei, is the most threatened small cetacean in the South Atlantic. Accidental captures in fishing nets is the main problem for this species throughout its distribution. Dead franciscanas found along the coast are an important source of information. This work aimed to analyze the records of dead franciscanas found on the northern coast of Santa Catarina, including Babitonga Bay. Between January 2001 
and November 2012, 54 franciscana carcasses were recorded, with the highest number (8 individuals) in 2011. Fifty-two percent $(\mathrm{n}=28)$ of the carcasses were recorded between August and October. Taking into account that this information was not obtained from a systematic effort, it was not possible to consider this as an estimation of mortality. The largest animal was a female, with a total length of $142 \mathrm{~cm}$. Ten recovered animals (18.5\%) were smaller than $80 \mathrm{~cm}$, and were considered fetuses or calves. These records indicate that the main birthing period for franciscanas in Santa Catarina is between October and January. The findings presented here contribute to our knowledge of franciscana ecology in the state of Santa Catarina.

Key words: Birth period; Pontoporia blainvillei; Santa Catarina; Stranding

\section{Introduction}

The franciscana (Pontoporia blainvillei) inhabits the coastal waters of the Western South Atlantic, from Itaúnas, Espírito Santo, Brazil (18²5'S) (MOREIRA; SICILIANO, 1991) to Baia de San Antonio, northern Patagonia, Argentina (42³5'S) (CRESPO et al., 1998). Four management areas were defined for the species, referred to as Franciscana Management Areas (FMAs), considering biological information (SECCHI et al., 2003). Santa Catarina State is included in FMA III, which also includes Paraná and São Paulo states, in southeastern Brazil.

Accidental capture in fishing nets is the main conservation issue for the species (SECCHI et al., 1997; KINAS, 2002; ROSAS et al., 2002; DI BENEDITTO, 2003; SECCHI et al., 2004; CAPOZZO et al., 2007). Hundreds of franciscana dolphins die each year as a consequence of getting entangled in gillnets. This problem led to the recognition of these animals as an endangered species (MMA, 2003; REEVES et al., 2008).

The occurrence of franciscana dolphins in Santa Catarina was first documented by Azevedo et al. (1982). Simões-Lopes and Ximenez (1993) presented more detailed information, including the individuals catalogued in Brazilian institutions, and information about strandings. In a review of the mammals of Santa Catarina State, Cherem et al. (2004) indicated that the species occurs along the coast of the whole state. Opportunistic sightings (FLORES, 2009), studies related to biological information, such as diet (CREMER et al., 2012), and comparative studies related to morphology (HIGA et al., 2002) and contamination (ALONSO et al., 2012; TORRE et al., 2012) are reported in the literature.
Despite the fact that Santa Catarina State has a strong fishery activity, including artisanal and commercial boats, little information is available on the levels of accidental captures of marine mammals. Simões-Lopes and Ximenez (1993) reported opportunistic information about cetacean interactions with fishing activities. Cremer et al. (1995) monitored for the first time a small artisanal fishery community at Farol de Santa Marta, in Laguna (28 $36^{\prime}$ 'S $48^{\circ} 49^{\prime} \mathrm{W}$ ). In that study, the authors estimated an annual capture of 120 franciscanas in that area. Henrique-Garcia et al. (2005) monitored a small artisanal fishery community in Barra Velha (26³8'S), and estimated a lower annual accidental capture. No information is available on the rate of accidental captures related to industrial fisheries.

On the northern coast of the state is a resident population in Babitonga Bay. This population was first recorded in 1996, and since then, some studies have been conducted with the aim of analyzing its ecology and behavior (CREMER; SIMÕES-LOPES, 2005; CREMER, 2007; CREMER; SIMÕES-LOPES, 2008; CREMER et al., 2012). This population was estimated at 50 individuals (CREMER; SIMÕES-LOPES, 2008).

The aim of this study was to present the records of franciscanas stranded dead on the northern coast of Santa Catarina State in the last twelve years to contribute to our knowledge of the species in this state, offering some insights into the birth period of the species in this region.

\section{Material and Methods}

In the period between January 2001 and November 2012 franciscana carcasses were recovered along the northern coast of Santa Catarina State, between coordinates $26^{\circ} 07^{\prime} \mathrm{S}$ and $26^{\circ} 38^{\prime} \mathrm{S}$. Most of the records 
were opportunistic, and the animals were located according to information given by local community. Posters were distributed periodically along the coast asking the community to alert us about any marine mammal stranded on the beach.

When possible, the animals were measured (total linear length, following Norris, 1961) and sexed by visual examination according Berta and Sumich (2003). Females were checked for pregnancy. Carcasses between decomposition levels 2 and 5 were necropsied as indicated by Geraci and Lounsbury (1993).

\section{Results and Discussion}

Between January 2001 and November 2012, 54 franciscana carcasses were recovered, 19 (35.2\%) of which were found in Babitonga Bay. Figure 1 shows the recovery locations. The skeletons were catalogued and deposited in the Acervo Biológico Iperoba mammal collection at Universidade da Região de Joinville (UNIVILLE), in São Francisco do Sul.

It was not possible to identify the sex for 26 individuals, and total length could not be determined for

FIGURE 1: Location of the carcasses of franciscanas on the north coast of Santa Catarina State ( $\mathrm{n}=54)$ between January 2001 and November 2012.

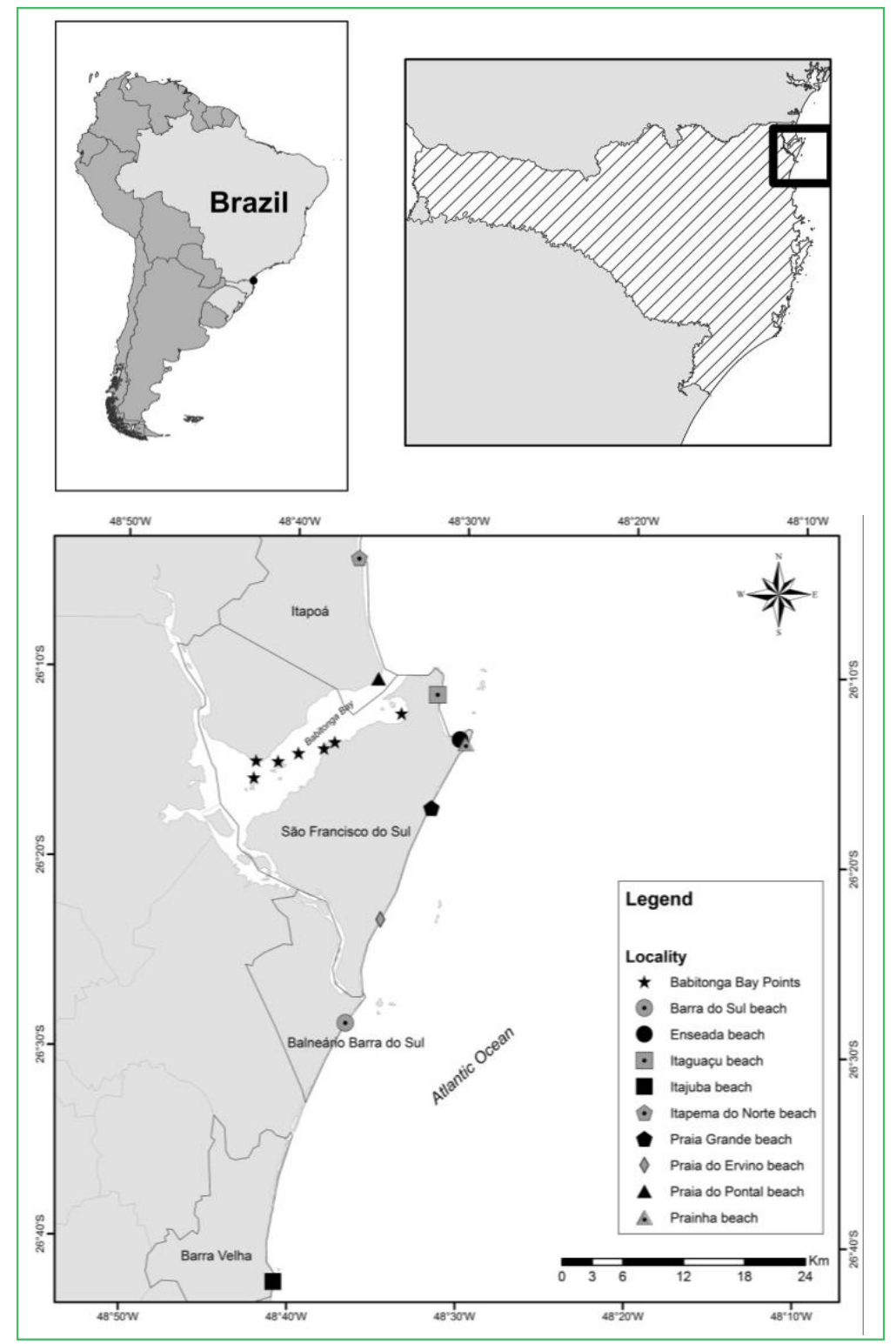


20 because of decomposition state of the animals. For some of these animals, the skeleton was not complete. Stranding date was recorded for all animals. We recorded dead franciscanas every year of the study period, and we found the largest number in 2011 (Figure 2). The highest number of carcasses recovered was in August, September and October (Figure 3), which accounted for $28(52 \%)$ of the carcasses.
The largest animal recorded was a $142 \mathrm{~cm}$ long female, stranded on the coast of Itapoá $\left(26^{\circ} 04^{\prime} \mathrm{S}\right)$ (Figure 4). Ten individuals (18.5\%) were less than $80 \mathrm{~cm}$ in length, indicating that they were calves or fetuses (ROSAS; MONTEIRO-FILHO, 2001; DANILEWICZ et al., 2002). Our data indicate that births occur between the months of October and January in Santa Catarina (Table 1). Two individuals

FIGURE 2: Number of dead franciscana dolphins $(n=54)$ recorded per year on the north coast of Santa Catarina State, January 2001 to November 2012.

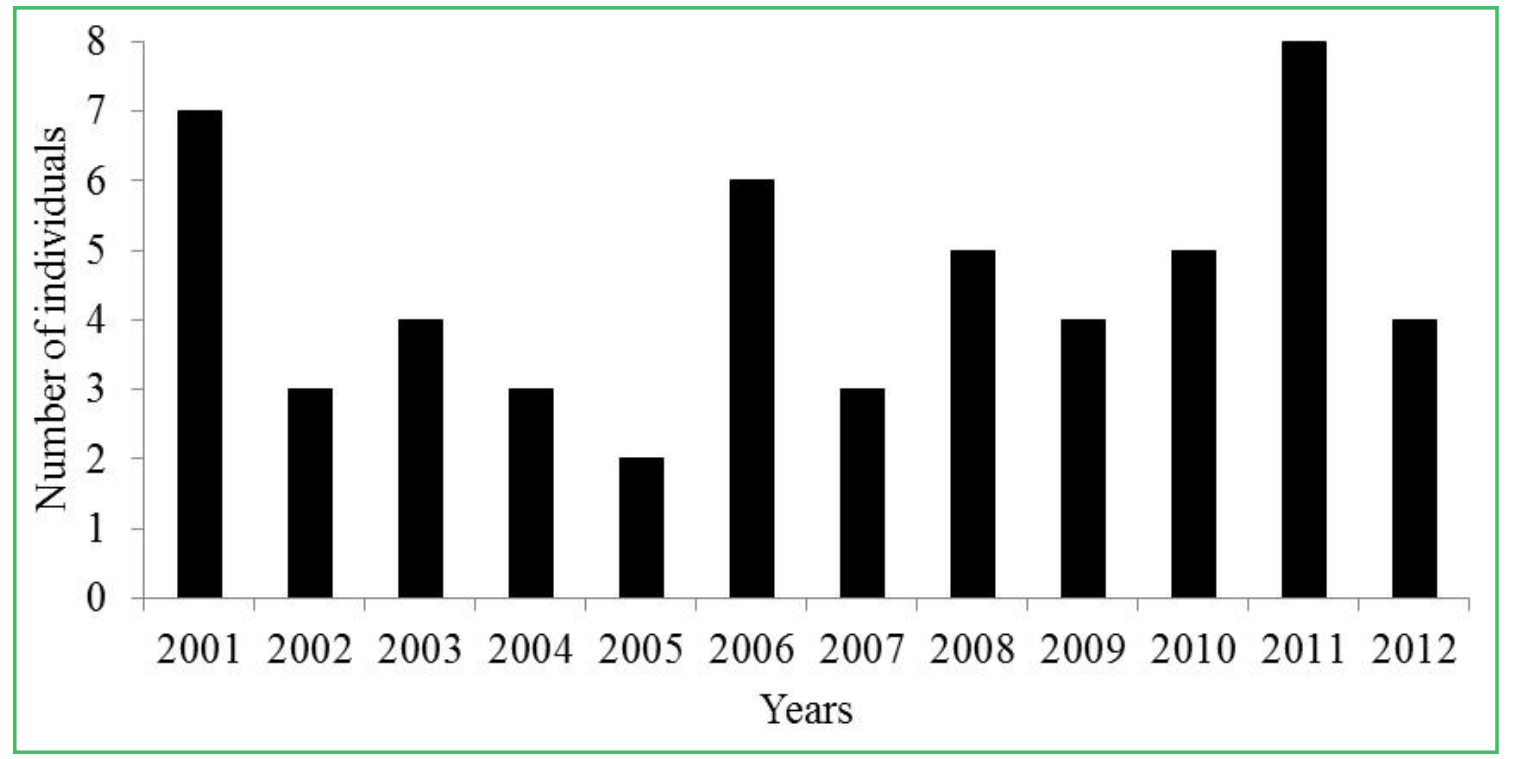

FIGURE 3: Number of dead franciscana dolphins recorded $(n=54)$ per month on the north coast of Santa Catarina State between January 2001 and November 2012.

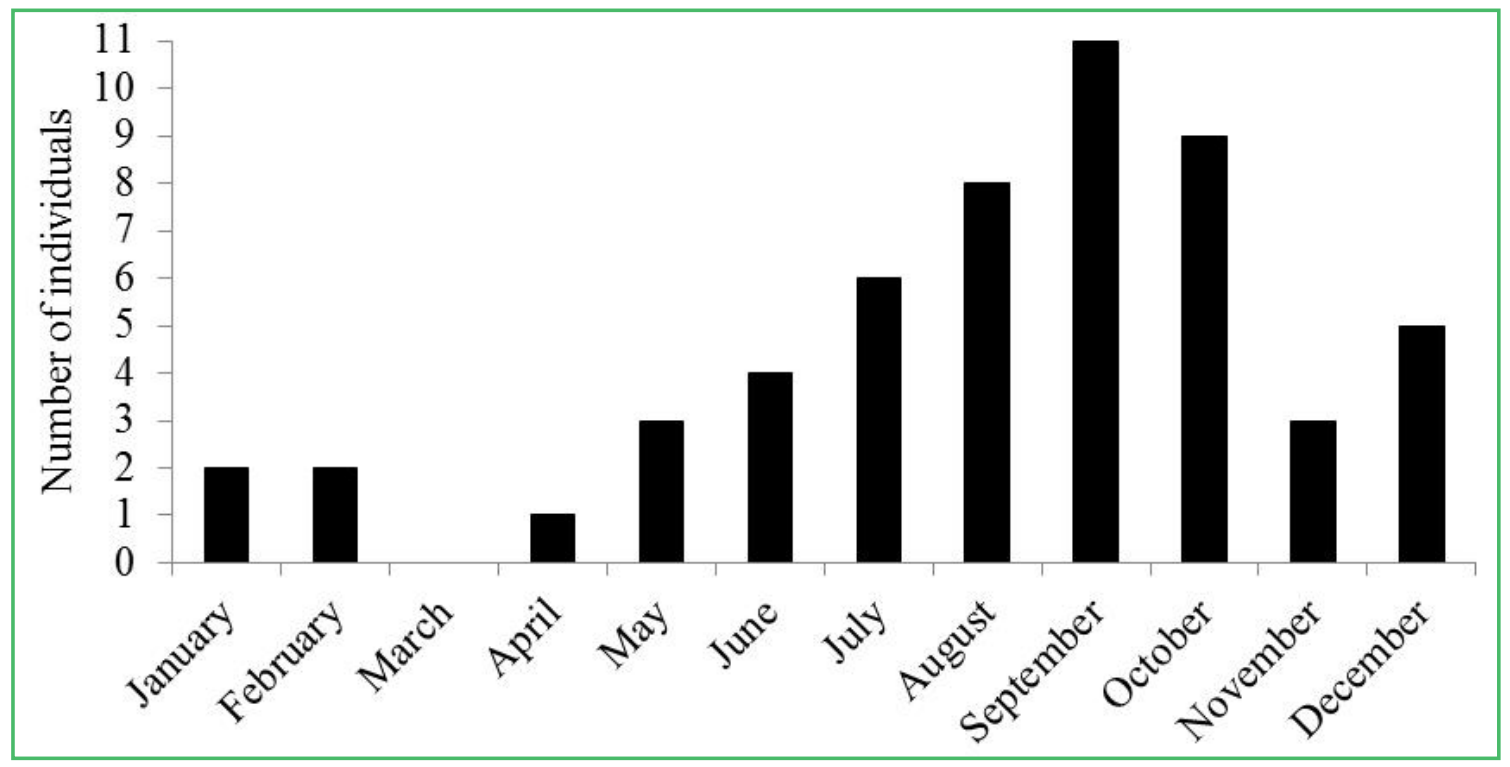


FIGURE 4: Size classes of dead franciscana dolphins $(n=34)$ recorded on the north coast of Santa Catarina State between January 2001 and November 2012.

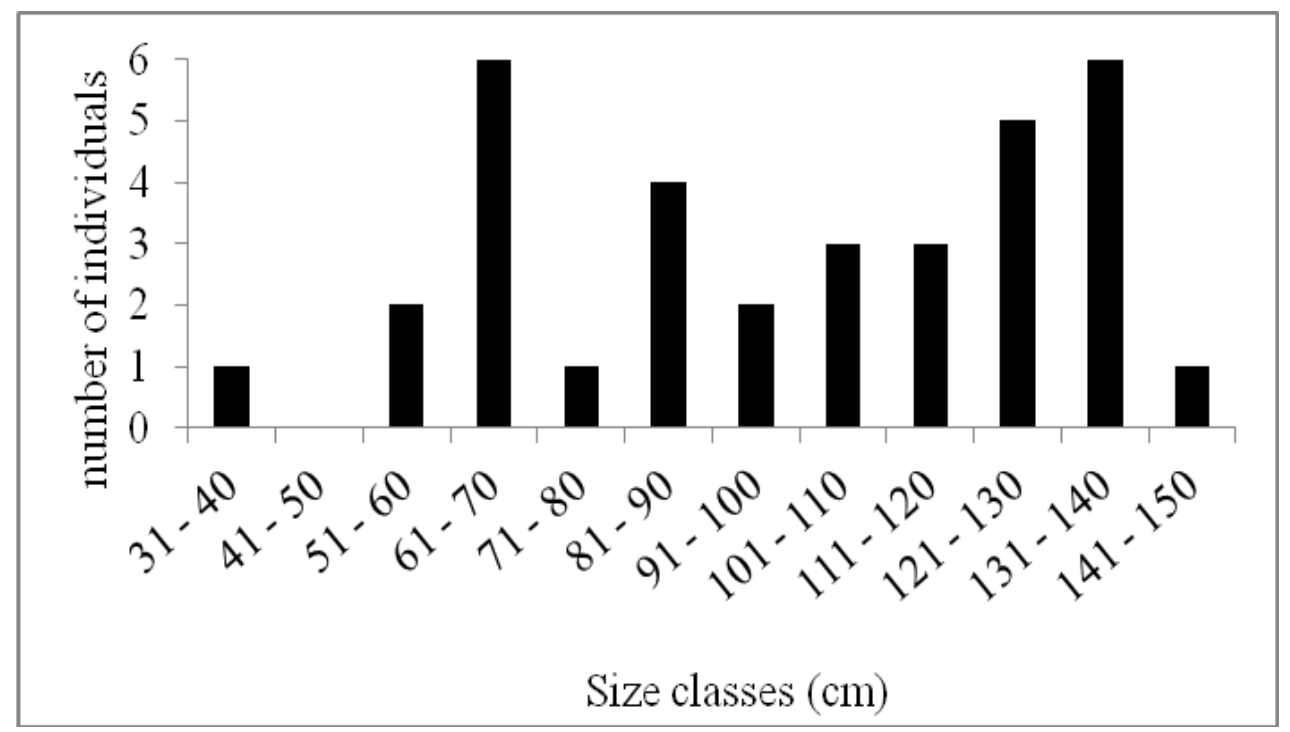

TABLE 1: Dead franciscana dolphins $(\mathrm{n}=10)$ less than $80 \mathrm{~cm}$ recovered on the north coast of Santa Catarina State between

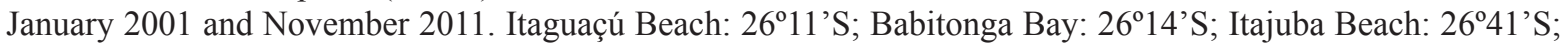

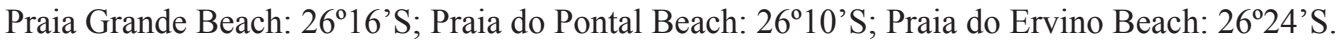

\begin{tabular}{|c|c|c|c|}
\hline No. & Total length (cm) & $\begin{array}{c}\text { Date } \\
\text { (month/day/year) }\end{array}$ & Recovery site \\
\hline UNIVILLE 005 & 62.90 & $10 / 09 / 2001$ & Itaguaçú Beach, São Francisco do Sul \\
\hline UNIVILLE 026 & 61.80 & $12 / 25 / 2003$ & Babitonga Bay, São Francisco do Sul \\
\hline UNIVILLE 044 & 73.00 & $01 / 13 / 2006$ & Babitonga Bay, São Francisco do Sul \\
\hline UNIVILLE 051 & 68.50 & $11 / 15 / 2001$ & Itajuba Beach, Barra Velha \\
\hline UNIVILLE 130 & 37.00 & 07/16/2001 & Babitonga Bay, São Francisco do Sul \\
\hline UNIVILLE 227 & 62.00 & $11 / 14 / 2009$ & Babitonga Bay, São Francisco do Sul \\
\hline UNIVILLE 253 & 60.00 & $10 / 09 / 2010$ & Praia Grande Beach, São Francisco do Sul \\
\hline UNIVILLE 322 & 60.30 & $10 / 15 / 2011$ & Praia do Pontal Beach, Itapoá \\
\hline UNIVILLE 232 & 67.00 & $10 / 23 / 2011$ & Praia do Ervino Beach, São Francisco do Sul \\
\hline UNIVILLE 333 & 68.00 & $12 / 03 / 2011$ & Babitonga Bay, São Francisco do Sul \\
\hline
\end{tabular}

were surely fetuses, retrieved from the females: UNIVILLE $130(37 \mathrm{~cm})$ and UNIVILLE $322(60.3$ $\mathrm{cm})$; the females were $138 \mathrm{~cm}$ and $142 \mathrm{~cm}$ in length, respectively. Applying the fetal growth rate of $7.55 \mathrm{~cm} / \mathrm{month}$ estimated by Rosas and MonteiroFilho (2001), the first fetus would have been born between November and December, and the second in November. The individuals between 60 and $70 \mathrm{~cm}$ could have been newborns or near-term fetuses.
There is no information about reproductive parameters for franciscana dolphins in Santa Catarina State. Rosas and Monteiro-Filho (2001) presented information for São Paulo and Paraná states $\left(25^{\circ} 00^{\prime} \mathrm{S}\right.$ $25^{\circ} 58^{\prime}$ 'S), concluding that franciscanas are born at $71.2 \mathrm{~cm}$, mainly between October and December. It seems that franciscanas in Santa Catarina are smaller, but the birth period is the same. Simões-Lopes and Ximenez (1993) mentioned a female found in a gillnet 
in Camboriu (26 59'S) that aborted a near-term fetus in October. Cremer et al. (1995) reported the accidental capture of one pregnant and lactating female in July along Cape Santa Marta Grande (28 $36^{\circ}$ 'S), with a 20 $\mathrm{cm}$ long fetus. This fetus would have been born between January and February, considering the fetal growth rate estimated by Rosas and Monteiro-Filho (2001).

The small calves reported here were probably related to the accidental capture of their mothers in fishing nets. Despite the fact that Brazilian law forbids the use of fixed gillnets along the coast of Santa Catarina State (Portaria IBAMA 54/1999), the nets are used extensively. For Babitonga Bay, a specific law allows fishermen to use driftnets inside the bay (Portaria IBAMA 84/2002) throughout the year, and these nets are commonly used between October and November (PINHEIRO; CREMER, 2003). This kind of net is strongly related to incidental captures and could be considered a significant threat to this population.

Data collection was not uniform along the coast and over time, and therefore, the information presented here could not be used to estimate mortality. Ferreira et al. (2010) reported that the majority of carcasses of franciscanas accidentally caught in fishing nets do not strand on the beach. The highest number of records in Babitonga Bay was related not only to our proximity to the area, which facilitated gathering information, but also to the occurrence of a resident population there (CREMER; SIMÕES-LOPES, 2005; CREMER; SIMÕES-LOPES, 2011). The continuous monitoring of the coast over time shall provide more detailed information about this species.

\section{Acknowledgments}

The authors are grateful to the staff of Laboratório de Nectologia who helped in animal recordings between 2001 and 2012. This work received financial support from the Universidade da Região de Joinville. The Projeto Toninhas/UNIVILLE is sponsored by Petrobras, through Programa Petrobras Ambiental. Dr. A. Leyva helped with English editing of the manuscript.

\section{References}

ALONSO, M. B.; ELJARRAT, E.; GORGA, M.; SECCHI, E. R.; MASSOI, M.; BARBOSA, L.; BERTOZZI, C. P.; MARIGO, J.; CREMER, M. J.; DOMIT, C.; AZEVEDO, A. F.; DORNELES, P. R.; TORRES, J. P. M.; LAILSON-BRITO, J.; MALM, O.; BARCELÓ, D. Natural and antropogenically-produced brominated compounds in endemic dolphins from Western South Atlantic: another risk to a vulnerable species. Environmental Pollution, Amherst, v. 170, p. 152-160, 2012.

AZEVEDO, T. R.; EL ACHKAR, D.; MARTINS, M. de F.; XIMENEZ, A. Lista sistemática dos mamíferos de Santa Catarina conservados nos principais museus do estado. Revista Nordestina de Biologia, João Pessoa, v. 5, n. 1, p. 93-104, 1982.

BERTA, A.; SUMICH, J. L. Marine mammals: evolutionary biology. San Diego: Academic Press, 2003. 494 p.

CAPOZZO, H. L.; NEGRI, M. F.; PÉREZ, F. H.; ALBAREDA, D.; MONZÓN, F.; CORCUERA, J. F. Incidental mortality of franciscana dolphin (Pontoporia blainvillei) in Argentina. Latin American Journal of Aquatic Mammals, Pacific Grove, v. 96, n. 2, p. 127-137, 2007.

CREMER, M. J. Ecologia e conservação de populações simpátricas de pequenos cetáceos em ambiente estuarino no sul do Brasil. 2007. 232 f. Tese (Doutorado em Zoologia) Universidade Federal do Paraná, Curitiba. 2007.

CREMER, M. J.; BRUTTO, L. F.; SIMÕES-LOPES, P. C.; DIEFENBACH, O. The incidental catch of Pontoporia blainvillei in Santa Catarina State, southern Brazil. In: BIENNIAL CONFERENCE ON THE BIOLOGY OF MARINE MAMMALS, 11, 1995, Orlando. Abstracts... Orlando: Biennial Conference on the Biology of Marine Mammals, 1995.

CREMER, M. J.; PINHEIRO, P. C.; SIMÕES-LOPES, P. C. Prey consumed by Guiana dolphin Sotalia guianensis (Cetacea, Delphinidae) and franciscana dolphin Pontoporia blainvillei (Cetacea, Pontoporiidae) in an estuarine environment in southern Brazil. Iheringia, Série Zoologia, Porto Alegre, v. 102, n. 2, p. 131-137, 2012.

CREMER, M. J.; SIMÕES-LOPES, P. C. The occurrence of Pontoporia blainvillei (Gervais \& d'Orbigny) (Cetacea, Pontoporiidae) in an estuarine area in southern Brazil. Revista Brasileira de Zoologia, Curitiba, v. 22, n. 3, p. 717-723, 2005.

CREMER, M. J.; SIMÕES-LOPES, P.C. Distribution, abundance and density estimates of franciscana, Pontoporia blainvillei (Cetacea: Pontoporiidae), in Babitonga bay, southern Brazil. Revista Brasileira de Zoologia, Curitiba, v. 25, n. 3, p. 397-402, 2008 .

CHEREM, J. J.; SIMÕES-LOPES, P. C.; ALTHOFF, S.; GRAIPEL, M. E. Lista dos mamíferos do estado de Santa Catarina, sul do Brasil. Mastozoologia Neotropical, San Miguel de Tucumán, v. 11, n. 2, p. 151-184, 2004.

CRESPO, E. A.; HARRIS, G.; GONZÁLES, R. Group size and distributional range of the franciscana, Pontoporia blainvillei. Marine Mammal Science, Vancouver, v. 14, n. 4, p. 845-849, 1998.

DANILEWICZ, D.; ROSAS, F.; BASTIDA, R.; MARIGO, J.; MUELBERT, M.; RODRÍGUEZ, D.; BRITO JR., J. L.; RUOPPOLO, V.; RAMOS, R.; BASSOI, M.; OTT, P. H.; CAON, 
G.; MONTEIRO DA ROCHA, A.; CATÃO-DIAS, J. L.; SECCHI, E. R. Report on the working group on biology and ecology. Latin American Journal of Aquatic Mammals, Rio de Janeiro, v. 1, n. 1, p. 25-42, 2002.

DI BENEDITTO, A. P. M. Interactions between gillnet fisheries and small cetaceans in northern Rio de Janeiro, Brazil: 2001-2002. Latin American Journal of Aquatic Mammals, Rio de Janeiro, v. 2, n. 2, p. 79-86, 2003.

FERREIRA, E. C.; MUELBERT, M.; SECCHI, E. R. Distribuição espaço-temporal das capturas acidentais de toninhas (Pontoporia blainvillei) em redes de emalhe e dos encalhes ao longo da costa sul do Rio Grande do Sul, Brasil. Atlântica, Rio Grande, v. 32, p. 183-197, 2010.

FLORES, P. A. C. Occurrence of franciscana (Pontoporia blainvillei) in Baía Norte, southern Brazil. Latin American Journal of Aquatic Mammals, Rio de Janeiro, v. 7, n. 1-2, p. 93 95, 2009.

GERACI, J. R.; LOUNSBURY, V. Marine mammals ashore: a field guide for strandings. Texas: Texas A\&M Sea Grant Publications, 1993. 305 p.

HENRIQUE-GARCIA, J.; BARRETO, A. S.; BARROS, L. T.; RUIZ, D. G. Mortalidade acidental de toninhas (Pontoporia blainvillei) em arte de pesca passiva na Praia da Canoa, Barra Velha, SC. In: CONGRESSO BRASILEIRO DE OCEANOGRAFIA, II, 2005, Vitória. Resumos... Vitória: Congresso Brasileiro de Oceanografia, 2005. Versão eletrônica.

HIGA, A.; HINGST-ZAHER, E.; DE VIVO, M. Size and shape in the skull of Pontoporia blainvillei (Cetacea: Pontoporiidae) from the Brazilian coast. Latin American Journal of Aquatic Mammals, Pacific Grove, v. 1, n. 1, p. 145-152, 2002.

KINAS, P. G. The impact of incidental kills by gill nets on the franciscana dolphin (Pontoporia blainvillei) in southern Brazil. Bulletin of Marine Science, Miami, v. 70, n. 2, p. 409-421, 2002.

MMA - MINISTÉRIO DO MEIO AMBIENTE. Lista nacional das espécies da fauna brasileira ameaçada de extinção. Instrução Normativa 03/2003. Brasília: MMA, 2003.

MOREIRA, L. M.; SICILIANO, S. Northward extension range for Pontoporia blainvillei. In: BIENNIAL CONFERENCE ON THE BIOLOGY OF MARINE MAMMALS, 9, 1991, Chicago. Resumos... Illinois: Biennial Conference on the Biology of Marine Mammals, 1991.

NORRIS, K. S. Standardized methods for measuring and recording data on the smaller cetaceans. Journal of Mammalogy, Lawrence, v. 42, n. 4, p. 471-476, 1961.
PINHEIRO, L.; CREMER, M. J. Etnoecologia e captura acidental de golfinhos (Cetacea: Pontoporiidae e Delphinidae) na Baía da Babitonga, Santa Catarina. Desenvolvimento e Meio Ambiente, Curitiba, v. 8, p. 69-76, 2003.

REEVES, R. R.; SMITH, B. D.; CRESPO, E. A.; NORTABARTOLO, G. D. Dolphins, whales and porpoises: 2002-2010 Conservation Action Plan for the World's Cetaceans. Gland \& Cambridge: IUCN/ SSC Cetaceans Specialist Group, 2008. 147 p.

ROSAS, F. C. W.; MONTEIRO-FILHO, E. L. A. Reproductive parameters of Pontoporia blainvillei (Cetacea, Pontoporiidae), on the coast of São Paulo and Paraná states, Brazil. Mammalia, Paris, v. 66, n. 2, p. 231-245, 2001.

ROSAS, F. C. W.; MONTEIRO-FILHO, E. L. A.; OLIVEIRA, M. R. Incidental catches of franciscana (Pontoporia blainvillei) on the Southern coast of São Paulo State and the coast of Paraná State, Brazil. Latin American Journal of Aquatic Mammals, Pacific Grove, v. 1, n. 1, Special Issue 1, p. 161-167, 2002.

SECCHI, E. R.; DANILEWICZ, D.; OTT, P. H. Applying the phylogeographic concept to identify franciscana dolphin stocks: implications to meet management objectives. Journal of Cetacean Research and Management, Cambridge, v. 5, n. 1, p. 61-68, 2003. SECCHI, E. R.; KINAS, P. G.; MUELBERT, M. Incidental catches of franciscana in coastal gillnet fisheries in the franciscana management area III: period 1999-2000. Journal of Cetacean Research and Management, Cambridge, v. 3, n. 1, p. 61-68, 2004. SECCHI, E. R.; ZERBINI, A. N.; BASSOI, M.; ROSA, L. D.; MOLLER, L. M.; ROCHA-CAMPOS, C. C. Mortality of franciscanas, Pontoporia blainvillei, in coastal gillnets in Southern Brazil: 19941995. Report of the International Whaling Commission, Cambridge, v. 47, p. 653-658, 1997.

SIMÕES-LOPES, P. C.; XIMENEZ, A. Annotated list of the cetaceans of Santa Catarina coastal waters, southern Brazil. Biotemas, Florianópolis, v. 6, n. 1, p. 67-92, 1993.

TORRE, A. L.; ALONSO, M.; MARTINEZ, M. A.; SANZ, P.; SHEN, L.; REINER, E. J.; LAILSON-BRITO, J.; TORRES, J. P.; BERTOZZI, C. P.; MARIGO, J.; BARBOSA, L. A.; CREMER, M. J.; SECCHI, E. R.; MALM, O.; ELJARRAT, E.; BARCELO, D. Dechlorane related compounds in franciscana dolphin (Pontoporia blainvillei) from Southeastern and Southern coast of Brazil. Environmental Science \& Technology, Arlington Heights, v. 302, p. 934, 2012. 